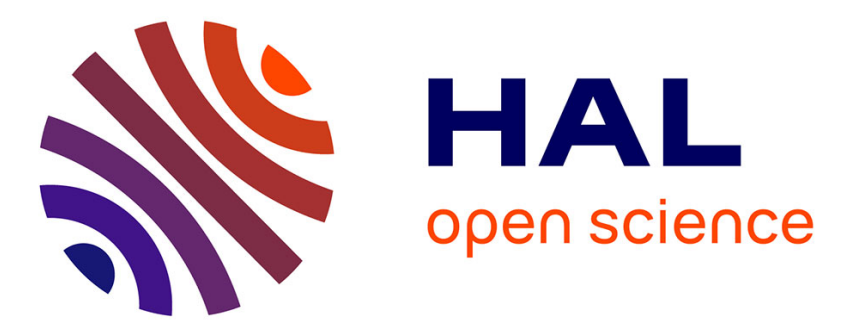

\title{
Backside Anti-Reflecting Absorbing Layer Microscopy for in situ Graphene Imaging and Modification
}

Stéphane Campidelli, Renaud Cornut, Vincent Derycke, Dominique Ausserré

\section{To cite this version:}

Stéphane Campidelli, Renaud Cornut, Vincent Derycke, Dominique Ausserré. Backside AntiReflecting Absorbing Layer Microscopy for in situ Graphene Imaging and Modification. 229th ECS Meeting, May 2016, San Diego, United States. cea-02351467

\section{HAL Id: cea-02351467 https://hal-cea.archives-ouvertes.fr/cea-02351467}

Submitted on 6 Nov 2019

HAL is a multi-disciplinary open access archive for the deposit and dissemination of scientific research documents, whether they are published or not. The documents may come from teaching and research institutions in France or abroad, or from public or private research centers.
L'archive ouverte pluridisciplinaire HAL, est destinée au dépôt et à la diffusion de documents scientifiques de niveau recherche, publiés ou non, émanant des établissements d'enseignement et de recherche français ou étrangers, des laboratoires publics ou privés. 


\title{
Backside Anti-Reflecting Absorbing Layer Microscopy for in situ Graphene Imaging and Modification
}

\author{
Stephane Campidelli ${ }^{1}$, Renaud Cornut ${ }^{1}$, Vincent Derycke, ${ }^{1}$ Dominique Ausserré ${ }^{2}$ \\ ${ }^{1}$ LICSEN, NIMBE, CEA, CNRS, Université Paris-Saclay, CEA Saclay 91191 Gif-sur-Yvette \\ Cedex, France. \\ ${ }^{2}$ Institut des Molécules et Matériaux du Mans (UMR 6283), Université du Maine, Avenue \\ Olivier Messiaen, 72000 Le Mans, France
}

Two-dimensional nanomaterials and their association into 2-D heterostructures have been extensively studied for the last couple of years. Thus, the development of new, versatile, highresolution visualization and placement techniques is highly desirable. It is well known that a single layer of graphene can be observed under optical microscopy on $\mathrm{Si} / \mathrm{SiO}_{2}$ substrates because of interference effects when the thickness of silicon oxide is optimized. ${ }^{1,2}$ However, differentiating monolayers from bilayers remains a challenge and advanced techniques like Raman mapping, Atomic Force or Scanning Electron Microscopy (AFM, SEM) are more suitable to observe monolayers of graphene. Raman mapping and AFM are relatively slow and SEM is operated in vacuum so that in all cases real-time experiments including chemical modifications are not accessible. Therefore, the development of techniques that combine the large scale and speed of SEM, the topological information of AFM and the simplicity optical microscopy may greatly facilitate the study of nanomaterials.

In our group, we are interested in particular forms of graphene derivatives which are graphene oxide (GO) and reduced graphene oxide (r-GO). While a single layer of graphene absorbs $2.3 \%$ of the incident light, ${ }^{3}$ graphene oxide monolayer exhibits a weaker light absorption that makes it almost impossible to distinguish on $\mathrm{Si} / \mathrm{SiO}_{2}$ surface. In 2007, Ruoff and co-workers were able to observe directly GO flakes using confocal microscopy; they even obtained higher contrast for $\mathrm{GO}$ than for graphene on $\mathrm{Si} / \mathrm{SiO}_{2}$. For that they optimized a substrate by depositing silicon nitride layers from 60 to $70 \mathrm{~nm}$ on silicon. ${ }^{4}$ Here we introduce a novel optical microscopy technique based on the use of Anti-Reflecting and Absorbing (ARA) layers yielding to ultra-high contrast reflection imaging of graphene monolayers in air or in water. We name this technique "Backside Absorbing Layer Microscopy" (BALM) and we illustrate its efficiency by in-situ imaging graphene oxide (see Figure) and its chemical modification.

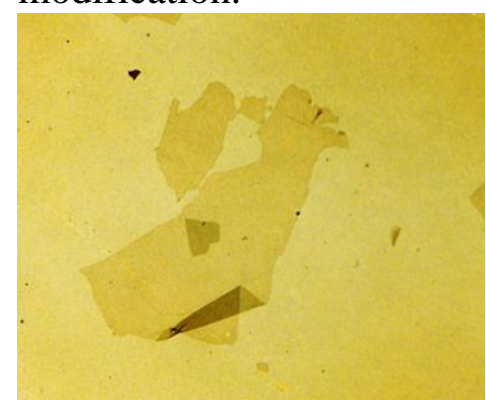

Figure. Wide field optical images of graphene oxide flake.

Reference List 
(1) Blake, P.; Hill, E. W.; Castro Neto, A. H.; Novoselov, K. S.; Jiang, D.; Yang, R.; Booth, T. J.; Geim, A. K. Appl. Phys. Lett. 2007, 91, 063124.

(2) Roddaro, S.; Pingue, P.; Piazza, V.; Pellegrini, V.; Beltram, F. Nano Lett. 2007, 7, 2707-2710.

(3) Nair, R. R.; Blake, P.; Grigorenko, A. N.; Novoselov, K. S.; Booth, T. J.; Stauber, T.; Peres, N. M. R.; Geim, A. K. Science 2008, 320, 1308.

(4) Jung, I.; Pelton, M.; Piner, R.; Dikin, D. A.; Stankovich, S.; Watchrotone, S.; Hausner, M.; Ruoff, R. S. Nano Lett. 2007, 7, 3569-3575. 